"This is an Accepted Manuscript of an article published by Taylor \&

Francis in Journal of Human Rights on 4/11/2015, available online:

http://wwww.tandfonline.com/10.1080/14754835.2015.1103161."

\title{
INTRODUCTION
}

Over the last decade and a half 'rights-based approaches' to development have embodied the principal way in which a rights discourse and practice has been incorporated across various international and national development NGOs. In light of the diverse interpretations of such approaches, researchers have predominantly focused on the numerous translations of 'rightsbased approaches' in theory and practice. Accordingly, various comparative analyses have emerged, contributing further to the dominant position that these approaches have come to occupy.

What is significant, however, is that despite such important areas for inquiry, the existing literatures have consequently ignored the extent to which different engagements with human rights have arisen outside of 'rights-based approaches'. That is, the preoccupation with understanding the various (genuine) interpretations, limitations and added values of such approaches has left an important gap within our understanding. Specifically a gap has emerged concerning the extent to which particular NGOs are firmly rejecting 'rights-based approaches' whilst concurrently developing alternative engagements with a human rights discourse and practice. The central purpose of this article is therefore to provide an initial analysis of some alternative engagements that have emerged, thereby enabling us to start to explore the potential nature of RBA rejection. Central to this is the underlying aim of actively encouraging further approaches to be considered and researched beyond the confines of this present contribution (with the future aim of establishing a comprehensive theory of RBA rejection).

Methodologically the article draws on empirical data gathered for a research project conducted during 2006-2014. The project was based on two stages of in-depth research, each 
with the purpose of providing a conceptual platform to recognise and examine various receptions of human rights discourses and practices. Stage one involved a comparative study of eight development NGOs. These consisted of three 'rights-based approach' NGOs (Save the Children, Oxfam and ActionAid) and five NGOs that had chosen not to adopt a 'rightsbased approach' (Christian Aid, Tearfund, CAFOD, the World Development Movement and War on Want). Key strategy papers and campaign documents were analysed, together with a series of focus groups and in-depth interviews with over 80 participants ${ }^{1}$. Stage two involved ethnographic research of three NGOs that had firmly rejected 'rights-based approaches'. A comparative selection of findings from stage one provide the focus for this article, and are used as a means to qualitatively illustrate various types of responses to 'rights-based approaches' - alongside alternative engagements with human rights - that are currently prevalent across two particular sub-categories of NGOs (details of which are discussed below).

The section that follows provides the context for the research project, outlining how trends in current 'rights-based approach' theory and practice have led to the omission of particular 'voices' within the existing literatures. This is followed by data drawn from the research project; illustrating the extent to which some NGOs are incorporating 'rights talk', and why they do so despite firm rejections of 'rights-based approaches'. A more focused analysis is then offered, concerning emerging engagements with human rights by the NGOs. The article lastly concludes by reflecting on the illustrative nature of key findings, and in so doing, calls for new areas of research to be developed.

\section{CONTEXTUALISING THE RESEARCH}

\section{The Ascendancy of 'Rights-based Approaches'}


For the purpose of providing context to the present analysis, an overview of 'rights-based approaches' (hereafter RBAs) is required. Since the mid-1990s, RBAs have come to occupy the dominant medium through which a human rights discourse and practice has proliferated across the mainstream development sector (in both the global South and North). Actors promoting RBAs have included United Nations agencies (UNDP, UNICEF), multilateral agencies (World Bank), major donors (the UK's departments for International Development and the Swedish International Development Cooperation Agency), international NGOs (Oxfam, Save the Children, ActionAid and CARE) and local grassroots NGOs and social movements (Cornwall and Nyamu-Musembi 2004; Gready and Ensor 2005; Hickey and Mitlin 2009; Kindornay, Ron and Carpenter 2012).

Literature on the topic has been essentially concerned with either establishing the meanings of RBAs in both theory and practice, and/or reviewing their progress and translation. This is unsurprising, given the range of actors that have promoted or adopted RBAs in a myriad of ways (see for instance, Uvin 2002; Ball 2005; Gready and Ensor 2005; Harris-Curtis, Marleyn and Bakewell 2005; Theis and O'Kane 2005; Hickey and Mitlin 2009; Kindornay, Ron et al. 2012; Gready 2013). In reflection of the diverse practices of RBAs, some have observed RBAs to represent 'a loose and ill defined idea, which everyone can adopt as they can interpret it to fit their own interests' (Harris-Curtis, Marleyn et al. 2005: 39-40). Whilst other commentators have identified them to represent 'a catchall [approach] for the complexity of the development issues and challenges facing institutions such as NGO' (Mitlin and Hickey 2009: 9). Fundamental to these observations has been the further identification that 'there is no single, coherent rights-based approach, but a range of tentative and highly varied commitments among development agencies' (Nelson and Dorsey 2008: 93). 
The evident myriad of approaches described as "rights-based approaches" has led to the earlier identification that RBAs represent a 'broad umbrella concept' (Miller 2011: 109). The identification of this concept emerged from existing research, which had frequently analysed the malleability of RBAs through a lens that essentially amounts to a 'one-approach-fits-all message' (see Miller 2010: 918). This message was (and indeed, still is) promoted through claims made across the existing literatures that commonly contend that RBAs should not be taken to represent a singular approach. Instead, the dominant discourses continue to argue that NGOs formally adopting RBAs should be examined for the multitude of ways in which a practice of rights has been incorporated across organisations (see Cornwall and NyamuMusembi 2004: 1431; Theis 2004: 19; Kindornay, Ron et al. 2012; Gready 2013).

Consequently such a recognition (and invariably, promotion) of the plurality of RBAs has led to the advancement of a prevailing message across existing research; essentially that the RBA label can cover most (or, at worst, all) incorporations of human rights practice across the mainstream development NGO spectrum. Thereby indicating a 'one-approach-fits-all message'. However, as the data below demonstrates, there is a growing trend across this sector, where formal RBAs are being firmly rejected by development NGOs, whilst a practice of rights has become increasingly centralised.

In order to examine why RBAs are being rejected the available definitions of RBAs must be briefly discussed. It is vital however to emphasize that the purpose of such an undertaking is not to present a finite taxonomy (as that would be contrary to the very findings presented here), but instead to identify the foundation on which a comparative analysis has been established. 
A key contribution to this area (and one that has been frequently cited because of its comprehensive overview) comes from Hamm (2001). Hamm argues that the 'main goal' of RBAs is to be the 'achievement of human rights as an objective of development' (2001: 10113). From this foundation, human rights standards and frameworks are then understood to offer the critical 'frame of reference for development policy' (2001: 1011-3). She builds on to this through the observation that RBAs commonly prioritise a focus on 'nondiscrimination', 'participation and empowerment', and 'good governance' (Hamm 2001: 11321).

Mitlin and Hickley's (2009) survey of RBA research has also led to the identification of RBA 'packages'. From this perspective, 'packages' (dependant on RBA 'interpretations') are likely to be inclusive of the following rights dimensions:

- (Pressure for) formal rights as laid down within some legal systems, stipulations, rules, or regulations

- The implementation of such rights through legal campaigns and stronger links with the legal profession

- A more complete system of interconnected rights, rather than single rights

- Adherence to international rights and a hierarchy of rights at local, national and international scales

- The explicit acknowledgement that engaging with rights requires an overtly political approach.

(Mitlin and Hickey 2009: 8)

Beyond such rights dimensions, RBAs are again noted to promote 'non-legal political processes', inclusive of: participatory citizenship; political transparency and accountability; and concern for those most marginalized (Mitlin and Hickey 2009: 8). It is also important to 
note that a strong emphasis on 'non-discrimination' appears to remain a core component of most RBA 'packages' (Cornwall and Nyamu-Musembi 2004; Gready and Ensor 2005).

On a broader level, there is an important distinction that has been noted concerning the divide between 'rights-based approaches' and 'human rights-based approaches'. For some, the latter represent a narrower focus (normatively and legally speaking), whilst arguably possessing a stronger moral claim to legitimacy. By contrast, the former represent a more broad-based focus (again, normatively and legally), thereby enabling appeals to a more expansive discourse of rights (which for instance may extend towards notions of citizenship). It is however more frequently accepted that 'rights-based approaches' offer a shorthand for 'human rights-based approaches' (see Eyben 2003; Piron 2005 for discussions on this matter). This second position furthers the observation that RBAs represent a 'broad umbrella concept', precisely because it allows for distinctions within the label of RBAs to be emphasised. To this end Cornwall and Nyamu-Musembi (2004) conclude:

... there is a clear line of distinction to be drawn between agencies who take a more legalistic approach, using human rights as standards against which development interventions might be assessed, and those for whom the realisation of human rights is seen as underpinning the entire development enterprise and therefore provides a more broad-based normative framework which requires a re-definition of development goals.

(Cornwall and Nyamu-Musembi 2004: 1431, emphasis in original)

Existing research consequently offers crucial insights into the ways in which RBAs have become central to development NGOs. Comparative studies provide a basis to contrast the various expressions of RBAs, adding context and meaning to our comprehension of what 
constitutes an RBA. Particular studies also tell us how various RBAs have been adopted for the purpose of increasing political leverage (through the appeal to legal 'obligations' of established 'duty bearers'), whilst also aiding the ever present requirement to justify the legitimacy of overall approaches to development (see for instance, Uvin 2004; Gready and Ensor 2005; Piron 2005; Miller 2010; Kindornay, Ron et al. 2012; Gready 2013). There are however three main areas that are somewhat limited within the current literatures - all of which are identified below as an omission or under representation of particular 'voices'. These are: voices of response to RBAs by campaigners; voices from within 'faith-based' and 'political' NGOs vis-à-vis the use and value of RBAs; and, a consideration for expressions of rights talk outside of RBAs.

\section{Omissions of 'Voice' and Analysing 'Rights Talk'}

The theory of 'voice' (as developed by Gilligan 1982; and Stanley 1990) was employed within the research project as a means to identify the various expressions of 'rights talk' articulated within the sector. The assumption of the research was built on the idea that by providing a platform for various voices to be both spoken and heard, the limitations of the broad umbrella concept could be examined. This shift in focus away from simply hearing voices within RBA-NGOs, provided the space for the emerging approaches to rights to be explored.

By comparison to the studies available, very little attention has been directed towards campaign experiences (see Nelson and Dorsey 2008 for a broader analysis of 'New Rights Advocacy'). That is, what the current literature does not comprehensively tell us is: how campaigners working in development NGOs have responded to RBAs. The significance of such voices is increased when we take into account that studies have also revealed that one of 
the 'major upheavals' associated with adopting RBAs has been the 'shift away from delivery of services towards advocacy and lobbying' (Harris-Curtis, Marleyn et al. 2005: 34; see also, Kindornay, Ron et al. 2012) and equally, towards 'campaigning about policy issues that affect developing countries' (Uvin 2004: 143)². Given the apparent importance of campaign activities in regards to RBA adoption, why then is there a near absence in the available literatures? The assumption of the project was that RBA research was yet to advance into new areas beyond those identified above (again, due to the earlier preoccupation with translations of theory into practice and strategies for change).

By incorporating theories of voice as an analytical tool, the research was also able to develop a further conceptual distinction. Underpinned by a Weberian construction of 'ideal types' (Weber 1925c/1978), the NGOs covered in the research were identified by three subcategories: '(mainstream) humanitarian and development', 'faith-based' and 'political'. These sub-categories were utilised as conceptual abstractions, enabling a more contextualised analysis of emerging trends. The abstractions were premised on the principal motivations and ideological foundations of each of the NGOs, respectively: liberal notions of goodness and humanitarianism; questions of faith and religion; and, political ideologies. The data analysed below focuses primarily on findings relating to two 'faith-based' and two 'political ${ }^{3}$ NGOs covered in the research.

The various RBA studies surveyed during the project provided detailed analyses of varying applications of RBAs. However, on closer scrutiny, it became apparent that such studies had done this from an overtly (mainstream) International humanitarian and development NGO perspective. Due to their size, degrees of influence and overwhelming acceptances of (and sustained efforts to adopt and promote) RBAs, such NGOs - for example, Oxfam, ActionAid, 
Save the Children and CARE - have emerged as the important subjects of inquiry (see for example Offenheiser and Holocombe 2003; Cornwall and Nyamu-Musembi 2004; Akerkar 2005; Brouwer, Grady and Traore 2005; Harris-Curtis, Marleyn et al. 2005; Plipat 2005; Theis and O'Kane 2005; Chapman, Miller, Soares and Samuel 2009; Kindornay, Ron et al. 2012; Gready 2013). It was therefore identified that even though this sub-category has much to offer research, by contrast the voices of faith-based and political NGOs are currently under represented.

Although little research has been conducted in regards to faith-based NGO responses to RBAs, there are however three studies that briefly contribute to this area more generally. First, Plipat (2005: 106-7) found that while forty per cent of the top thirty international development NGOs had a 'religious association', not one had adopted an RBA. From this he concluded that 'religious' NGOs are more likely to base their approaches on their own teachings than on a human rights framework, whilst also suggesting a general 'impression' of such NGOs as 'non-adopters and quiet supporters' (2005: 107). Second, Harris-Curtis (2003: 562) found that some 'Christian' NGOs have rejected RBAs, not because they deem 'rights as unimportant', but because they identify themselves to be part of 'another value system'. And third, Tomalin (2006) provided a broader analysis of various religious responses to RBAs (that is, beyond religious NGOs per se). She concluded that RBAs inherently 'ignore' religious differences and cultural diversities, and that often they focus too much on claiming rights, thereby neglecting corresponding duties (2006: 95). From this basis she called for a more 'inclusive RBA', where the goal of 'equitable development' should be 'culturally appropriate' (2006: 93). 
By contrast, the voices of political NGOs appear to be absent in existing research. An apparent reason for this (and equally the limited focus on faith-based NGOs) appears to be that such literatures have been concerned with genuine efforts to adopt and promote RBAs throughout NGO practice, rather than research those that employ a more instrumental approach. However, as the findings below demonstrate, significant insight can be gained from these varying perspectives, adding a further dimension to our understanding of the various practices of human rights across the NGO spectrum.

In order to advance these lines of analyses, and as part of the broader interpretative sociological approach adopted, the research project also drew on the analytical concept of 'rights talk'. The premise for this was taken from critical observations developed by social anthropologist, Richard Ashby Wilson. Wilson (2006: 77-83), in his analysis of the Truth and Reconciliation Commission in South Africa, identified ways in which the concept of human rights enables a broad range of social and political actors to come together often with 'openly contradictory' political claims. This, he observes, builds further to the 'plural and fragment nature of the international rights regime and the ideological promiscuity of rights talk' (2006: 77). Consequently the project aimed to observe varying ways in which campaigners might take advantage of the ideological promiscuity of rights talk, with the purpose of advancing campaign objectives.

\section{TRANSCENDING RIGHTS-BASED APPROACHES: CAMPAIGNERS，}

\section{VOICES}

The selection of data presented below is offered to be indicative to the wider trends observed across the research project. The first half of the data covers a sample of responses made by campaigners from within two of the faith-based NGOs covered in the study: Tearfund and 
CAFOD. The former is an evangelical Christian NGO, working in partnership with Christian agencies and churches worldwide, whilst the later works internationally as the official Catholic agency for England and Wales. The second section presents a sample taken from two of the ('leftist') political NGOs coved: War on Want and the World Development Movement (hereafter, WoW and WDM respectively ${ }^{4}$ ). Both are internationally focused NGOs, working in partnership with radical social movements fighting against the root causes of global poverty, inequality and injustice. The premise for identifying each NGO within their respective sub-categories was based on official policy and strategy papers, as produced by the NGOs ${ }^{5}$. Beyond their sub-categorisation and international remit, all four NGOs: perform a campaigning function; and operate as generalist (rather than specialist) development NGOs. Added to this, all four have firmly chosen not to adopt an RBA.

\section{Responses to Rights-Based Approaches: Faith-based NGOs}

Participants from within CAFOD and Tearfund expressed various responses to RBAs. Most responses were in regards to the reasons why they felt faith-based NGOs should avoid adopting them. The overriding theme that appeared to unite their responses was in relation to the values they understood RBAs to promote.

One particular (and I would suggest, wonderfully ironic) concern frequently raised was in relation to the property of 'universality'. This largely appeared problematic for many campaigners from the premise that universalism is insensitive to cultural difference. In particular, the claim that universal rights are part of a Western liberal bias was repeatedly suggested. The following statement, made by one of CAFOD's senior campaigners, provides an illustration of this charge: 
We need to be very cautious about these "fundamental human rights"... There are huge positives [to RBAs], but I would say to any organisation that you cannot limit yourself to just that, it is much more complicated... for me, gospel values are about saying, "I am here respecting where you are and I don't want to change you, I actually want to help you be more yourself... I am not imposing anything on you."

(CAFOD Senior Campaigner, Interview, October 2012)

This statement was offered as a comparison to the weaknesses suggested vis-à-vis the application of RBAs. Like many CAFOD participants, the distinction is made between a faith-based approach, driven by Catholic Social Teaching, and a more restricted 'legalistic' expression of RBAs (as observed by Cornwall and Nyamu-Musembi 2004: 1431). RBAs were essentially critiqued for their application of the discourse of rights based on an overly normative understanding and use. From this basis, such applications are considered by the research participants to risk the promotion of a cultural hegemony, through their reflection of the Western philosophies that influenced their origins and construction. Accordingly many campaigners suggested a cultural relativist critique, where the idea of human rights is not rejected per se, but rather a Western application of it is.

Fundamental to the charge of a Western bias, was also a critique of the influence of Western individualism. Explicitly, the majority of participants (within CAFOD and Tearfund) stressed the importance of collective action over the concept of individual rights. The idea that RBAs focused too much on the individual was frequently identified to be a significant weakness, and was thus often compared to faith-based teachings, where emphasis is consistently directed towards the context of the community. 
A broader RBA issue repeatedly raised by the campaigners was in relation to some negative evangelical Christian responses to the concept of human rights. First, it was suggested that an 'unnecessary caution' exists within fractions of the evangelical church around the concept of human rights (senior campaigner, Tearfund). This was perceived to be largely as the result of key 'iconic' issues. Specifically, the framing of universal access to abortion and also to samesex marriage within the language of rights by a number of social movements was identified to have had a largely negative impact. Various campaigners noted that the strong position taken by many within the evangelical Christian church against such 'rights' had increased the concern over the promotion of RBAs - with many within the church aligning a discourse of rights to 'shrill extremism' (Tearfund's Campaigns and Advocacy Director).

Second, Tearfund participants noted a tension regarding the idea of demanding rights (for instance, 'I demand my right to an abortion'). While it was suggested that 'claims' were inherent in all by virtue of their humanity (synonymous to a natural law position), the basis for understanding such claims was a theological tension. This tension emerged around the extent to which 'claims' should be understood as 'rights' or 'gifts'. The participants explained that while both concepts may practically end in the same result (for example, achieving equality), theologically they required a different response before God. When articulated as a 'right', some participants suggested that no response was required before God, as conceptually 'rights' represent a fundamental demand which all are entitled to. However when articulated as a 'gift' from God, a response of gratitude was expected to flow, precisely because 'gifts' cannot be demanded, but are instead given as a result of care and compassion.

And third, some participants noted a concern regarding the tension between 'human rights struggles' and 'God given struggles' (campaigner, CAFOD). Essentially the latter was 
distinguished because of the authoritative command it assumed. By contrast, 'human rights struggles' were identified to relate to vast areas, which at times could present not only the potential of conflicting rights, but also a potential conflict with faith-based teachings. Again reference was made to the claim for the 'right to abortion', as a primary area where a conflict of beliefs might emerge.

\section{Rights Talk Outside of Rights-Based Approaches: Faith-based NGOs}

Despite the above tensions with the conceptual groundings and applications of RBAs, participants suggested expressions of rights talk outside of RBAs. At the broadest level, two dominant trends appeared to emerge across the data. The first was in regards to a more restricted understanding of rights talk, presented by various participants from within CAFOD. By contrast, the second was in reflection of a more pragmatic and instrumental use of rights talk, identified by Tearfund participants. These trends will be addressed respectively.

The key way in which CAFOD participants appeared to understand and interpret various claims articulated in the language of rights was based on the formal framework of the Universal Declaration of Human Rights (UDHR). The UDHR essentially represented a codified set of standards, reflecting a secular interpretation of a number of values, with particular reference being made to notions of dignity and equality. From this perspective, participants suggested a personal sense of compatibility between the UDHR and Catholic Social Teaching, however most also emphasised the different ideological foundations between the two. Namely, the first was identified for having emerged through a consensus of political ideologies, whilst the latter was understood to have been the result of various religious experiences, and so for that reason, carried an authoritative command from the higher status. The following statement, made by CAFOD's campaigns director, provides 
some insight into this understanding, and moreover, reveals an important tension in regards to the relationship between rights and duties:

Human Rights is a different language but it is the same thing to me in lots of ways. Catholic Social Teaching talks not of the right of every person, but the dignity of every person, to be able to live a full and happy life ... It's the same thing; it is just a different codification. However Catholic Social Teaching says more to me than any rights-based approach type language could say - in terms of understanding your role, your responsibilities and your relationship with God.

(CAFOD Campaigns Director, Interview, November 2012)

Accordingly, while some similarities are seen between Catholic Social Teaching and the values expressed through the language of rights, a contrast is identified between Catholic Social Teaching and the duties presupposed within the discourse of rights. Within the wider context of this statement, the interviewee suggested a critique of the dominant discourses of rights, as defined by the UDHR. This critique was based on the understanding that the UDHR speaks only implicitly of duties that involve respect for rights, while faith-based teachings promote an explicit duty to take action and essentially care for communities that are marginalized, oppressed and living in poverty. From this perspective the participants asserted that there would be little to gain by incorporating rights talk within campaign practice, identifying Catholic Social Teaching to offer a more holistic framework and structure for campaign strategies.

By contrast, Tearfund participants suggested a rather different understanding and subsequent use of rights talk. The most prevalent theme identified across many of the interviews was the 
understanding that, in various ways, a human rights discourse represented a tool to be used within faith-based approaches. One of the most direct orientations towards this idea came from Tearfund's campaigns and advocacy director. The following statement exemplifies this perspective through the director's reflection of a position paper given by Tearfund's theological advisor:

[Our theological advisor] said, "actually rights are okay, they are a very useful tool, they are just not the complete story." So in a sense, if there is an official Tearfund position, it is that. ... We are not against rights, we actually think many rights are very good and should be recognised, and they are even based on biblical principles... To me the UDHR is just another way of saying what I profoundly believe from my Christian faith, repackaged in a modern day language... It's just that only thinking of rights, and not of responsibilities, is not [enough].

(Tearfund Campaigns and Advocacy Director, Interview, January 2008)

This statement reveals an understanding and interpretation of the various claims articulated in the language of rights as a contemporary repackaging of biblical principles. Overwhelming the perceived sense of common ground between both sets of values enables a more instrumental application of rights talk. Consequently, while RBAs are essentially rejected due to their normative application, a human rights framework appears to be implicitly incorporated, though crucially driven by faith-based teachings. Again the limitations of the UDHR are highlighted in relation to the absence of explicit 'responsibilities', however this time such limitations do not offer a reason to reject a rights framework per se. That is, from this perspective the absence of responsibilities appears to be accommodated for, precisely because a human rights framework represents an implicit component within Tearfund's overall approach. 
Participants from within Tearfund also suggested different ways in which they incorporated the language of human rights within campaign activities. A particular example that was offered on a number of occasions was in regards to Tearfund's campaigning on universal access to water and sanitation, where it had explicitly proclaimed 'water is a human right' (Tearfund 2005; Tearfund 2006; Tearfund 2013). By utilising the language of rights, Tearfund repackaged the notion of 'dignity' through a human rights frame, for the purpose of appealing to the moral idea (rather than any legal quality) of universal rights. For instance, it purposely aligned the dignity of women with the realisation of the 'right to water', arguing that without access to water, poverty and suffering are caused, thus reinforcing the conceptual value of the right (2005: 5). Consequently, the participants reflected on the various ways in which rights talk had been used as a political tool to advance claims for a minimum standard as an acceptable outcome. One participant also explained how the reframing of biblical concepts within a 'modern' and 'secular' language had enabled key principles to become more accessible to those outside of Tearfund's normal supporter base, whilst crucially remaining consistent with Tearfund's overall values and ideology.

On a more general level, all participants from within Tearfund noted that different audiences required different 'languages' for practical and strategic reasons. Distinct differences were suggested between how campaigners understood and interpreted various claims articulated in the language of rights, compared to that of the various internal departments and external audiences to Tearfund. Accordingly on occasions campaigners would appeal to the language of rights if it were perceived to 'strengthen' the message of campaign calls, whilst on other occasions such language was suggested to detract from the overall message. 
This sense of pragmatism was especially considered in regards to popular campaign messaging. Explicitly, decisions to 'use' the language of rights where 'appropriate', seemed to be measured by the power rights talk was understood to invoke, whilst also being balanced against the 'word count' it induced. By contrast the event of parliamentary lobbying was frequently identified to be a context where the use of the language of rights was deemed to be beneficial. Essentially it appeared that a degree of political leverage and legitimacy was at times assumed, and thus where appropriate, reference would be made to key international conventions and standards.

Accordingly the apparent absence of a conceptual grounding within the discourse of rights (as seen in RBAs) seemed to offer Tearfund considerable freedom to take advantage of the opportunities that rights talk might afford to particular campaign settings (and, likewise, to omit such a discourse when it appeared to offer no value to the campaign context or phase).

\section{Responses to Rights-Based Approaches: ('Leftist') Political NGOs}

The principal way in which the participants from within the political NGOs spoke of RBAs was based on the understanding that they start from and are defined by formal human rights frameworks. From this perspective RBAs were considerably critiqued precisely because of their dependency on such frameworks.

One of the major issues consistently raised by most of the participants was in regards to what was considered to be the failure of the concept of human rights to respond to the impact of globalization. Specifically the central concern was that while corporations have grown in global power and influence, the political discourse of rights has not responded to address this. For the participants this appeared to be a major weakness and accordingly a strong reason to 
suggest a rejection of RBAs. The premise for this was a direct reflection of their conceptual understandings of poverty, which were based on the consequences of neo-liberal economic policies and the advancement of global capitalism. The following statement, made by a senior campaigner at WoW, provides some insight into this concern:

... the people who drafted the UN system couldn't conceive the amount of corporate power there is in the world today. Today corporations are legal entities with their own rights, and yet [their actions,] which are so damaging, with such massive implications on peoples' lives, go ahead unrestricted. How can you base an entire approach on something that doesn't even account for this? Instead, it needs to be challenged peoples' rights and corporate entities ... It's an area where nobody really has a solution. So we're trying to be in there with [other organisations], with formulating positions on how you go about restricting power.

(WoW Senior Campaigner, focus group, April 2012)

Implicit within this critique is the perception that the idea of human rights presupposes a social contract. However this contract only extends as far as states and their citizens, and not corporations and their workers, or corporations and the communities they work within. The central assumption is that through the processes of globalization - with the emergence of large corporations and the assumed declining role of the state - the foundation of the concept of human rights is considerably weakened. Interviewees frequently explained that a political analysis leads them to contest the very power of multinational corporations, calling instead for accountability of actions, binding regulations and ultimately the progressive realisation of fundamental rights. Indeed the absence of this dimension within the dominant political discourses on human rights appeared to provide one of the main reasons to suggest a rejection 
of RBAs. Instead participants particularly noted that a key role of WoW and WDM was to be part of the wider global movement that seeks to challenge corporate power. Considerable skepticism was thus suggested in regards to whether a rights discourse could actually provide a suitable channel for challenging such dimensions of power.

Accordingly the participants frequently questioned what dimensions of power an RBA could offer campaign practice. By way of illustration, the following statement reveals the considerable frustrations experienced by one campaigner during a previous employment for an RBA-NGO ${ }^{6}$ :

[RBAs] don't actually provide you with any great benefits... Do you immediately get redress under the law? Well it was quite clear you don't! In fact you can spend an enormous amount of time concocting legal arguments as to why $\mathrm{x}, \mathrm{y}$, and $\mathrm{z}$ is in contravention of various rights... In my experience the most the Committee of the CRC can do is slap them on the wrist, [saying] "this is awful, you seem to be abusing people's rights." And [governments] don't like it, sure they would prefer not to be slapped, but there is no teeth at all... no enforceable mechanisms throughout the whole of the UN system. I used to ask myself, what is the point? [RBAs] just get you nowhere.

(WoW Executive Director, Interview, May 2011)

Here the Executive Director makes specific reference to the limited power of the Committee on the Rights of the Child, however the sentiment of this argument was also echoed across many of the participants. From this perspective, the value of utilising an overt rights framework as a premise to drive campaign activity is significantly measured by the extent to which legal leverage can be achieved. As the statement illustrates, this participant strongly 
criticized NGOs that adopt RBAs, from the perspective that an over dependence on legal discourses and mechanisms is largely ineffective, not least because of the time invested. This experience of RBA practice consequently fell within the 'legalist', and not the more 'broadbased', expression of RBAs (as observed by Cornwall and Nyamu-Musembi 2004: 1431).

Within the wider context of the statement above, the Executive Director also compared the restricted power of rights mechanisms to that of the World Trade Organisation (WTO). Specifically the 'soft law' and lack of 'teeth' of the Committee on the Rights of the Child was juxtaposed to sanctions imposed by the WTO. Accordingly, international mechanisms were not only critiqued because of their lack of power to enforce and regulate, but more so, due to the lack of will inherent within the political discourses of the international community. The main message was that NGOs could not rely on the political will of the leaders of industrialised nations to uphold obligations to protect, respect and fulfil fundamental rights, since such actors were identified to serve the interests of global capitalism first and foremost. In the light of this, considerable criticism was repeatedly directed towards other development NGOs that use an RBA and subsequently rely on governments to uphold international obligations. The following statement highlights this concern:

Different development NGOs can point to international agreements, [saying] "there are these rights and they are not being delivered". But what I haven't really worked out is whether anyone cares! So called "universal rights" are abused everyday across the world... somebody clearly doesn't care, and if that somebody is the target of your campaign, then they probably are not going to be swayed. There needs to be something else.

(WDM, Campaigner, Interview, May 2012) 
This statement reveals a significant degree of apathy with an over-reliance on the very social actors identified to be among some of the chief violators of human rights. That is, while participants frequently suggested an agreement with the moral idea of universal rights, they equally questioned the benefit of utilising a rights framework as a basis to challenge inequality, injustice and oppression. As the statement notes, substantial emphasis is placed on influencing campaign targets, and thus while some targets may be persuaded by the power of the idea of universal rights, the understanding is that most will not. Central to this critique is also an overriding paradox of relying on a framework to overcome poverty, which has essentially been constructed by the very social actors that are understood to violate and neglect fundamental rights in the pursuit of their own interests.

\section{Rights Talk Outside of Rights-Based Approaches: ('Leftist') Political NGOs}

Despite the overt rejection of starting from a human rights framework as a basis to drive campaign strategies, participants from within WDM and WoW did however identify a number of occasions where rights talk was used.

In the case of WDM, the main areas that were discussed were in relation to WDM's Dirty Aid, Dirty Water and food sovereignty campaigns. Like Tearfund, WDM had also framed its campaign for universal access to clean water through the language of rights. However WDM (unlike Tearfund) had explicitly located this argument not only in the idea of universal human rights, or even just the language of rights, but it also appealed to the establishment of the right to water at the national (UK) and international (UN) level (WDM 2006; see also, WDM 2014). 
During one of the interviews a senior campaigner identified that WDM's framing of the message was a particular response to the wider international movement, which was calling for the establishment of an enforceable right to water. Consequently the senior campaigner questioned whether such a decision would be taken again in the future, without the full force of an international movement. It was thus clear that the use of a human rights frame represented more of a tactical anomaly, rather than any strategic development to WDM's approach (that is, towards an RBA). As part of the explanation of this very idea, the senior campaigner noted:

We wouldn't refer to conventions for the sake of doing it. If there was a campaign that we were running that had a strong human rights element... and we felt that tactically it was an important thing to do, in terms of helping people to understand it, in that kind of gut feeling sort of way, we would... [but] I don't think you must do it. You have to be a bit wary of coming up with a framework where you say everything has to sit within it. It is more what makes sense within each campaign.

(WDM, Senior Campaigner, Interview, 17 April 2009)

This perspective, like many offered by the WDM participants, identifies the need for flexibility and pragmatism when campaigning. Essentially what is perceived to work for one campaign may not always work for another, with strategies changing both across campaigns and also within each campaign phase. From this basis, this particular participant suggested a firm critique of NGOs that always couched campaign messages within the language of rights, stating that such strategies often appeared 'opportunistic' and consequently weakened the message of campaign calls. Instead, it was assumed that the benefit of incorporating a human rights message should be considered on a campaign-by-campaign basis, rather than as an 
overall strategy. Furthermore, they explained that explicit reference to the language of rights, and indeed the specific citation of international standards, was to be used only where the moral force of the idea of universal rights was identified to have some strategic value (vis-àvis encouraging activists to take action).

Participants from within WoW also discussed various ways in which rights talk was incorporated within certain campaign contexts. In particular it was noted that WoW frequently utilised the language of rights within its Palestine campaigns. Such contexts appeared to lend themselves to a strategic use of rights talk, enabling WoW to purposely frame Palestinian development together with an end to the occupation, through a discourse of rights. Campaign calls were frequently based on the idea of universal rights, as promoted through a number of international rulings, standards and agreements. For example this was seen vis-à-vis citations of: the ICJ ruling of 2004; the obligations as set out within the Fourth Geneva Convention; and breaches of article 2 in the EU-Israel Association Agreement (see War-on-Want 2007; War-on-Want 2007; War-on-Want 2014). Some participants also noted how such appeals were essentially based on the understanding that the use of rights talk contributed to the justification of campaign calls, which, at times was presumed to provide further legitimation to WoW's approach before various audiences (see Miller 2012). Added to this, the appeal to rights talk was also suggested to add political and moral (rather than legal) leverage to broader campaign messages. However, like WDM, participants also noted that the utilisation of rights talk was highly dependent on specific campaign contexts and phases, and was certainly not to be used across all campaigns.

\section{ALTERNATIVE PERSPECTIVES AND APPROACHES}


Data above are illustrative of how specific campaigners have responded to the emergence and dominance of RBAs across the wider development sector. The contextualization of voices within faith-based and ('leftist') political NGOs provides for a more in-depth comparative analysis. Trends in responses not only suggest commonalities within the two sub-categories, but also wider reasons to reject RBAs, and more critically, alternative engagements with a discourse of rights.

For the campaigners within the faith-based NGOs, the primary response (manifested as a central apprehension) was the concern over the various values promoted through a human rights discourse, with particular reference being made to: the property of universality; the promotion of individualism; and the emphasis of rights before duties. Significant consideration was also given to the broader evangelical Christian responses to the concept of rights, which have at times been associated with 'shrill extremism' and a conflict between human rights claims and faith-based teachings. In contrast, campaigners within the political NGOs firmly rejected RBAs, from the understanding that such approaches are driven by a normative application of the international rights discourse. This rejection stems from a resistance to the political discourse on rights, which is perceived to be too liberal, and therefore incompatible with their particular (socialist) ideologies. Specific concern was also emphasized in regards to: the growing power of corporate elites; the limited power of international rights mechanisms; and the lack of political will to enforce international standards.

By not restricting the analysis to the broad umbrella concept of RBAs, the data significantly develops Harris-Curtis et al.'s (2005: 17) passing identification that the rejection of RBAs is 
not the same as a rejection of human rights. Instead, alternative engagements with a human rights discourse and practice are observed across all four NGOs.

First, data demonstrates how the faith-based NGOs are incorporating rights talk within campaign strategies whilst also being driven conceptually by their faith-based teachings (rather than being based on a normative application of rights, as promoted through RBAs). In particular, voices revealed how Biblical values are at times being framed within the language of rights, for the purpose of benefiting from the political and moral leverage assumed through a human rights discourse. This was not seen to alter the NGOs' value base per se, but rather promote it through a 'modern' and 'secular' language. For others the idea of universal rights is being promoted as a 'key issue', integrated as a component within campaign activities. Consequently from this basis it can be argued that the voices expressed within the faith-based NGOs do not need to be interpreted as 'non-adopters and quiet supporters' of RBAs (Plipat 2005: 107), neither, I suggest, is there a need to call for a more 'inclusive RBA' (Tomalin 2006: 93). Instead, such utilisations of rights talk should be seen as alternative engagements with human rights, and thus the concept of RBAs must be seen for its limitations.

Likewise, data concerning voices within the ('left') political NGOs demonstrate how the rejection of RBAs may not be the same as the rejection of a human rights discourse or practice. The examples of WDM's Dirty Aid Dirty Water and food sovereignty campaigns and WoW's Palestine campaigns reveal how particular strategies are at times being framed through rights talk. In these examples, the campaigns illustrate how campaigners will not only appeal to the idea of universal rights, or even just to the language of rights, but they will at times even call for a new human right to be established and enforced within international law. In contrast to RBAs, these examples also demonstrate how rights talk is being used only 
in specific contexts because it is understood to strategically advance the overall objective of a particular campaign, and most critically, fulfill a specific ideology of development.

Accordingly such examples illustrate a more pragmatic use of rights talk, driven by a strong political analysis and used for the purpose of drawing on the momentum of broad-based social movements.

In light of the significance of this contextualised analysis, the two sub-categories of NGOs reveal an important distinction in voice. This distinction builds on and contributes to the existing literatures, by establishing why some campaigners might utilise rights talk despite a firm rejection of RBAs. This distinction can be explained by what I suggest to be different 'perspectives'. The identification of these perspectives emerges directly from the analysis of the research project, and is based primarily on the types of questions campaigners appear to be asking in relation to the human rights discourse. These perspectives can be summarised by the following sets of questions:

- Values Perspective - Campaigners within faith-based NGOs ask: what are the values promoted through the human rights discourse? To what extent are such values consistent with those promoted through our own ideological base? And, are there any benefits for us to repackage our values within the language of human rights?

- Power Perspective - Campaigners within ('left') political NGOs ask: how far can the international human rights system be used to regulate and restrict the power of corporate elites and international institutions? To what extent is there the political will to enforce international human rights standards? And, is there any benefit in appealing to the idea of universal rights within particular campaign contexts? 
These two perspectives have implications for the potential ways in which RBAs have been rejected, and moreover, how and why alternative engagements with human rights have emerged. Explicitly a values perspective has enabled campaigners from within faith-based NGOs to incorporate rights talk as a tool, precisely because biblical values can be repackaged within the 'modern day language' of human rights. Meanwhile, a power perspective has allowed for campaigners within ('leftist') political NGOs to incorporate rights talk in particular campaign contexts for pragmatic reasons, whilst basing the overall approach on a strong political analysis.

However what unifies the incorporation of rights talk across both the faith-based and political NGOs covered in this study is the identification of a more instrumental use. Such use represents examples of what have been identified as 'rights-framed approaches' (Miller 2011). Essentially, the human rights discourse is being embedded through a process of framing, in a way that serves either a political analysis or faith-based teaching, like a tool advancing its work. From this basis the use of rights talk is not only driven by such (religious or 'leftist'/socialist) ideologies, but it is also used to promote and advance their particular visions of development. Core to this is the further identification that rights talk may be invoked on particular occasions, whilst it can be strategically excluded on others (thereby taking advantage of the ideological promiscuity of rights talk, as observed by Wilson 2006: 77). Consequently (and, significantly in contrast to RBAs) an instrumental use of rights talk does not indicate a conceptual framework, but rather a strategic repackaging of ideas.

\section{CONCLUSION}


Existing research has told us very little about how voices within non-RBA NGOs have responded to RBAs. In particular, the voices within faith-based NGOs had been significantly underrepresented, whilst there has been an absence of voices within political NGOs. Consequently, the findings from this study provide new insights that advance the existing literatures.

Through incorporating 'rights talk' as an analytical tool, the limitations of the broad umbrella concept of RBAs have been exposed. That is, specifically because the notion of rights talk has been acknowledged, the analysis embedded within the research project has been able to expand beyond the concept of RBAs. The data analysed accordingly enables the identification of two new perspectives ('values' and 'power') and new approaches ('rightsframed approaches') to be identified and proposed. These perspectives and approaches are of both conceptual and applied importance. Conceptually, they challenge the boundaries of the broad umbrella concept of RBAs (and accordingly the preoccupation with RBAs within the existing literatures), and instead provide an initial platform from which distinct voices and approaches might be further analysed. This in turn is of applied significance; as such a contribution urges future research to consider not merely the application of RBAs, but more significantly, that of alternative engagements with human rights.

This research consequently stimulates a key debate concerning the need to examine alternative engagements with a human rights discourse and practice. Indeed, as noted from the outset of this article, the underlying aim of this contribution was to actively encourage further approaches to be considered and researched beyond the confines of this present analysis. Accordingly future research could advance the findings established here through the analysis of a wider range of development NGOs - with specific reference to NGOs located 
within the global South. As part of this, two particular areas might be considered. First, there is space to research more diverse voices within 'political' and 'faith-based' NGOs (which, for instance, might include those located within the tradition of the political right, or NGOs encompassing a broader religious experience). And second, investigations into different sets of sub-categories of NGOs would enable the advancement of a further analysis of the wider sector.

\section{ENDNOTES}

${ }^{1}$ Interviews and focus groups were conducted between 2007 and 2014. For ethical reasons participants are identified by role only.

${ }^{2}$ This claim does not suggest that RBA NGOs shift solely towards campaign activities (despite Harris-Curtis et al's earlier wording) but instead that campaigning has become a central part of their work (by contrast to pure service delivery). For further discussion and empirical data, see Harris-Curtis, Marleyn et al. (2005); Kindornay, Ron et al. (2012) Plipat (2005) and Uvin (2004).

${ }^{3}$ It is imperative to note here that the two 'political' NGOs covered in this article are located more to the left of the political spectrum, and consequently their rejection is only suggested to be indicative of similar NGOs with a 'leftist' political leaning. This is naturally by contrast to the many groups that would fall within different fractions on the full political spectrum. This is also addressed in the concluding section

${ }^{4}$ As of January 2015 the World Development Movement formerly changed its name to Global Justice Now. All data collection related to this article was completed by January 2015, therefore the original name has been used.

${ }^{5}$ For detailed information concerning each NGO, see CAFOD (ND); Christian Aid (ND); TEARFUND (ND); War on Want (ND); WDM (ND) 
${ }^{6}$ Due to the content of this statement, both the interviewee and the particular NGO in reference have been further anonymised.

\section{REFERENCES}

AKERKAR, Supriya. (2005). Rights, Development and Democracy: A Perspective From India. Reinventing Developement? Translating Rights-Based Approaches From Theory into Practice. Paul Gready and Jonathan Ensor (eds) (London: Zed Books).

BALL, Oliva. (2005). Conclusion. Reinventing Development?: Translating Rights-Based Approaches from Theory into Practice. Paul Gready and Jonathan Ensor (eds) (London: Zed Books)

BROUWER, Marjolaine, GRADY, Heather and TRAORE, Valerie (2005). The Experience of Oxfam International and Its Affiliates in Rights-Based Programming and Campaigning. Reinventing Development? Translating Rights-Based Approaches, from Theory into Practice. Paul Gready and Jonathan Ensor (eds) (London: Zed Books).

CAFOD (ND) [Online]. Available: http://www.cafod.org.uk [03 September 2015]

CHAPMAN, Jennifer, MILLER, Vallerie, SOARES, Adriano and SAMUEL, John (2009). Rights-Based Development: The Challenge of Change and Power for Development NGOs. Rights-Based Approaches to Development: Exploring the Potential and Pitfalls. Sam Hickey and Diana Mitlin (eds) (Sterling, VA: Kumarian Press): 165-185.

CHRISTIAN AID (ND) [Online]. Available: http//www.christainaid.org.uk/ [03 September 2015]

CORNWALL, Andrea. and NYAMU-MUSEMBI, Celestine. (2004). "Putting the 'RightsBased Approach' to Development into Perspective." Third World Quarterly 25(8): 1415-1437.

EYBEN, Rosalind. (2003). The Rise of Rights: Rights-Based Approaches to International Development. (Brighton: Institute of Development Studies).

GILLIGAN, Carol. (1982). In a Different Voice: Psychological Theory and Women's Development. (Harvard, MA: Harvard University Press).

GREADY, Paul. (2013). "Organisational Theories of Change in the Era of Organisational Cosmopolitanism: Lessons from ActionAid's human rights-based approach." Third World Quarterly 34(8): 1339-1360.

GREADY, Paul and ENSOR, Jonathan (2005). Introduction. Reinventing Development? : Translating Rights-Based Approaches from Theory into Practice. Paul Gready and Jonathan Ensor (eds) (London: Zed Books)

GREADY, Paul. and ENSOR, Jonathan. (Eds.) (2005). Reinventing Development? Translating Rights-Based Approaches From Theory into Practice. (London: Zed Books).

HAMM, Briggette. (2001). "A Human Rights Approach to Development." Human Rights Quarterly 23(4): 1005 - 1031.

HARRIS-CURTIS, Emma. (2003). "Rights-Based Approaches - Issues for NGOs." Development in Practice 13(5): 558-564.

HARRIS-CURTIS, Emma, MARLEYN, Oscar. and BAKEWELL, Oliver (2005). The Implications for Northern NGOs of Adopting Rights-Based Approaches. (Oxford: INTRAC).

HICKEY, Sam. and MITLIN, Diana. (Eds.) (2009). Rights-Based Approaches to Development: Exploring the Potential and Pitfalls. (Sterling, VA: Kumarian Press). 
KINDORNAY, Shannon, RON, James, and CARPENTER, Charli. (2012). "Rights-Based Approaches to Development: Implications for NGOs." Human Rights Quarterly 34(2): 472-506.

MILLER, Hannah. (2010). "From 'Rights-Based' to 'Rights-Framed' Approaches: A Social Constructionist View of Human Rights Practice." International Journal of Human Rights 14(6): 915-931.

MILLER, Hannah. (2011). From 'Rights-Based' to 'Rights-Framed' Approaches: A Social Constructionist View of Human Rights Practice. Sociology and Human Rights: New Engagements. P. HYNES, Michele. LAMB, Damien. SHORT and Matthew. WAITES. (London: Taylor and Francis).

MILLER, Hannah. (2012). "A Change in Charity Law for England and Wales: Examining War on Want's Foremost Adoption of the new Human Rights Charitable Purpose." International Journal of Human Rights 16(7): 1003-1022.

MITLIN, Diana. and HICKEY, Sam. (2009). The Rise of Rights-Based Approaches to Development. Rights-Based Approaches to Development: Exploring the Potential and Pitfalls. Sam Hickey and Diana Mitlin (eds) (Sterling, VA: Kumairan Press).

NELSON, Paul and DORSEY, Ellen. (2008). New Rights Advocacy: Changing Strategies of Development and Human Rights NGOs. (Washington: Georgetown University Press).

OFFENHEISER, Raymond and HOLOCOMBE, Susan. (2003). "Challenges and Opportunities in Implementing a Rights-Based Approach to Development: An Oxfam America Perspective." Non Profit \& Voluntary Sector Quarterly 32(2): 268-306.

PIRON, Laure-Helena. (2005). "Rights-Based Approaches and Bilateral Aid Agencies: More Than a Metaphor?" IDS Bulletin: Developing Rights 36(1): 19-30.

PLIPAT, Stephen. (2005). Developmentalizing Human Rights: How Development NGOs Interpret and Implement a Human Rights-Based Approach to Development Policy, Thesis. Graduate School of Public and International Affairs. Pittsburgh, University of Pittsburgh. PhD.

STANLEY, Liz. (1990). Feminist Praxis and the Academic Mode of Production: An Editorial Introduction. Feminist Praxi: Research, Theory and Epistemology in Feminist Sociology. L. Stanley. (London: Routledge): 3-19.

TEARFUND (2005). Why Advocate for Water, Sanitations and Hygiene? (Pamphlet). (Teddington: Tearfund).

TEARFUND (2006). Advocacy Strategy: 2006 - 2009. (Teddington: Tearfund).

TEARFUND. (2013). "'Water and Sanitation'." [Online]. Available: http://www.tearfund.org/en/about_us/what_we_do_and_where/issues/water_and_sanit ation/ [1 August 2015]

TEARFUND (ND) [Online]. Available: http://www.tearfund.org/ [03 September 2015]

THEIS, Joachim. (2004). Promoting Rights-Based Approaches: Experiences and Ideas from Asia and the Pacific. (Stockholm and Bangkok: Save the Children Sweden).

THEIS, Joachim. and O'KANE, Claire. (2005). Children's Participation, Civil Rights and Power. Reinventing Development? Translating Rights-Based Approaches from Theory into Practice. Paul Gready and Jonathan Ensor (eds) (London: Zed Books).

TOMALINE, Emma. (2006). "Religion and A Rights-Based Approach to Development." Progress in Development Studies 6(2): 93-106.

UVIN, Peter. (2002). "On High Moral Ground: The Incorporation of Human Rights by the Development Enterprise." PRAXIS, The Fletcher Journal of Development Studies XVII: $1-11$.

UVIN, Peter. (2004). Human Rights and Development. (Bloomfield, CT: Kumarian Press). 
WAR ON WANT (2007). "Letter to Kenneth Duncan, Senior Manager, Compliance and Support, UK Charity Commission, 26/06/2007" Internal Letter. (London: War on Want).

WAR ON WANT (2007). "Peace in Palestine" Leaflet. (London: War on Want).

WAR ON WANT (2014). "'The Wall must Fall - 10 Years Justice Denied'." [Online].

Available: http://waronwant.org/campaigns/justice-for-palestine/the-wall-must-fall [18 August 2015]

WAR ON WANT (ND) [Online]. Available: http://www.waronwant.org [03 September 2015]

WDM (2006). WDM Supporting Briefing October 2006: Water is a Human Right. (London: WDM).

WDM (2014). "'What is Food Sovereignty'." [Online]. Available: http://www.wdm.org.uk/food-sovereignty [18 August 2015]

WDM (ND) [Online]. Available: http://www.wdm.org.uk/ [04 December 2014]

WEBER, Max. (1925c/1978). "Bureaucracy". Economy and Society, Vols. 1 and 2. G. Roth and C. Wittich. (Berkeley, CA: University of California Press).

WILSON, Richard. Ashby. (2006). "Afterword to "Anthropology and Human Rights in a New Key": The Social Life of Human Rights." American Anthropologist 108(1): 7783. 